\title{
anemon
}

Muş Alparslan Üniversitesi Sosyal Bilimler Dergisi

Journal of Social Sciences of Muş Alparslan University

Yı//Year: 2017 • Cilt/Volume: 5 • Sayı/Number: 1

ISSN: 2147-7655 • e-ISSN: 2149-4622

ÖZGÜN ARAŞTIRMA ○ ORIGINAL ARTICLE

\section{Ortaöğretim Matematik Öğretmenlerinin Matematiksel Modelleme Yöntemi ve Uygulamalarına Yönelik Görüşleri ${ }^{\text {a }}$}

\author{
Demet DENIZ ${ }^{1, b}$, Levent AKGÜN ${ }^{2}$ \\ ${ }^{1}$ Yrd. Doç. Dr., Muş Alparslan Üniversitesi, Eğitim Fakültesi- Muş/ Türkiye \\ ${ }^{2}$ Yrd. Doç. Dr., Atatürk Üniversitesi, Eğitim Fakültesi- Erzurum/ Türkiye \\ Başvuru tarihi: 05 Aralık 2016 Düzeltme tarihi: 25 Aralık $2016 \quad$ Kabul tarihi: 11 Ocak 2017
}

Öz

$\mathrm{Bu}$ araştırmanın amac1, ortaöğretim matematik öğretmenlerinin matematiksel modelleme yöntemine ve bu yöntemin sınıf içi uygulamalarına yönelik görüşlerini belirlemektir. Çalışma Ağrı il merkezindeki dört farklı lise türünde görev yapan 13 matematik öğretmeni ile yürütülmüştür. Araştırmada olgu bilim deseni kullanılmıştır. Veriler yarı yapılandırılmış ön ve son görüşme formları ile toplanmıştır. Elde edilen veriler içerik analizi ile analiz edilmiştir. Öğretmenlerin matematiksel modelleme yöntemiyle ilgili önbilgilerini belirlemek amaciyla ön görüşmeler yapılmıştır. Yapılan ön görüşmelerden sonra matematiksel modelleme yöntemi tanıtılmıştır. Öğretmenlerden modelleme etkinlikleri tasarlamaları ve bu etkinlikleri sınıflarında uygulamaları istenmiş̧tir. Tasarlanan etkinlikler sınıflarda uygulandıktan sonra öğretmenler ile matematiksel modelleme yöntemi ve yapılan uygulamalar ile ilgili son görüşmeler yapılmıştır. Öğretmenler, matematiksel modellemeyi uygulama süreci sayesinde model oluşturma etkinliklerini tasarlayabilme ve uygulayabilme becerisini kazandıklarını belirtmişlerdir.

\section{Anahtar Kelimeler}

Matematiksel Modelleme, Model Oluşturma Etkinlikleri, Ortaöğretim Matematik Öğretmenleri

\footnotetext{
a Bu çalışma, 2014 yılında Atatürk Üniversitesi Eğitim Bilimleri Enstitüsü tarafından kabul edilen "Ortaöğretim Matematik Öğretmenlerinin Matematiksel Modelleme Yöntemine Uygun Etkinlik Oluşturabilme ve Uygulayabilme Yeterlikleri" adlı Doktora tezinden türetilmiştir.

b Sorumlu Yazar/Correspoding Author: Muş Alparslan Üniversitesi Kampüsü, Eğitim Fakültesi, İlköğretim Matematik Öğretmenliği Bölümü, 49250, Muş / Türkiye.

e-posta: demetdeniz227@gmail.com
} 


\title{
High School Mathematic Teachers' Views about Mathematical Modelling Method and Applications
}

\begin{abstract}
The aim of this study is to determine high school mathematics teachers' views about the mathematical modelling method and classroom applications of this method. The study was conducted with 13 high school mathematics teachers working in 4 different high school types in Ağrı city center. Phenomenological design was used in the study. Semi-structured pre and post interview forms were used as data collection tool. The data obtained were analyzed by content analysis. Pre-interviews were conducted in order to determine the prior knowledge of the teachers about the mathematical modelling method. After pre-interviews, the mathematical modelling method was introduced. The teachers were asked to design modelling activities and apply these activities in their classes. The teachers applied the activities they designed in their classes and they were interviewed about the mathematical modelling and the applications at the end of the process. The teachers reported that they acquired skills in designing and implementation of activities.
\end{abstract}

\section{Keywords}

Mathematical Modelling, Model Eliciting Activities, High School Mathematics Teachers

\section{GÍRİŞ}

Matematik dersindeki başarının büyük oranda zeki olma ile ilişkilendirilmesinden, matematik konularının soyut olmasından ve matematiği günlük hayatta kullanabilmek için değil sınavlarda başarılı olabilmek için öğrenilmesinden dolayı matematik ezberlenmesi gereken, sevimsiz bir derse dönüşmektedir (Baki, 2008; Uğurel ve Moralı, 2006). Hâlbuki matematik eğitiminin amacı matematiği günlük yaşamında etkili bir şekilde kullanabilen ve böylece matematikten korkmak yerine ondan zevk alan ve onu seven bireylerin yetişmesidir (Doruk, 2010). Bu yüzden matematik öğretiminde daha çok öğrencilerin günlük hayatlarında matematiğin önemini anlayabildikleri ve günlük hayatlarında gerçek matematiksel problemleri çözebildikleri örnekler ele alınmalıdır (Kaiser ve Schwarz, 2006). Matematik derslerinde yaygın olarak kullanılan problemlere bakıldığında bu problemlerin öğrencilerin matematiği gerçek hayatta uygulama becerilerini geliştirmekte yetersiz kaldığı görülmektedir (Erbaş vd., 2016). Gerçek hayat problemleri ile matematik arasındaki ilişkileri içeren matematiksel modellemenin rolü bu bakımdan önemlidir.

Matematiksel model bir problem durumunu matematiksel olarak ifade edebilmek için zihinde var olan veya oluşturulan denklem, fonksiyon, grafik ve matematiksel düşünme becerileri gibi yapılardır (Kertil, 2008). Matematiksel modelleme ise gerçek hayat problemlerinin soyutlandığı, matematikselleştirildiği, çözüldüğü ve değerlendirildiği 
periyodik bir döngü olarak tanımlanır. Dolayısıyla matematiksel modelleme, matematik ile gerçek hayat arasındaki boşluğu azaltan düzenli ve dinamik bir yöntem sunmaktadır (Ortiz ve Dos Santos, 2011). Lesh ve Doerr (2003) model ve modelleme terimlerini anlam bakımından içeren bir kavram olarak, modelleme etkinlikleri yerine, model ortaya çıkarma etkinlikleri (MOE) kavramını kullanmaktadır (Doruk, 2010). Günlük yaşamdaki bir problemi matematiği kullanarak çözebilen öğrencilerin matematiği öğrenmeye yönelik motivasyonları artar (Erbaş vd., 2016). MOE matematiksel model oluşturma, tahminde bulunma, değerlendirme ve genelleme gibi sosyal işlevler hedeflenerek tasarlanırlar ve elde edilen ürünler paylaşılabilir olmalıdır (Zawojewski, Lesh ve English, 2003). Dolayısıyla matematiksel modelleme çalışmaları için en uygun model grup çalışmasıdır (Antonius, Haines, Jensen, Niss ve Burkhardt, 2007; Maa $\beta$, 2006). Grup çalışmasının olması öğrencilere sosyal öğrenme ortamı sunar ve onların iletişim becerilerinin gelişmesinde katkıda bulunur.

Matematiksel modelleme her ne kadar önemli bir yöntem olarak görülse ve öğretim programlarında yer alsa bile okullarda uygulanamadığı müddetçe matematik öğretimine bir faydası olmayacaktır. Bu yöntemin faydalı olabilmesindeki temel faktörlerden birisi ise öğretmenlerdir. Öğretmenlerin görüşleri ise modellemenin uygulanacağı sınıf kültürünün oluşmasında etkilidir (Chapman, 2007). Dolayısıyla bu yöntemi uygulayacak öğretmenlerin görüşlerini tespit etmek önemlidir.

Matematiksel modelleme etkinliklerine yönelik öğretmen görüşlerini inceleyen araştırmalara bakıldığında; Yu ve Chang (2011) çalışmalarında hizmet içi eğitimle dokuz haftalık bir derste bir MOE tasarlanmış, bu etkinlikler uygulanmış ve uygulama sonrası 16 ortaokul öğretmeni ile görüşmeler yapmışlar ve modelleme yönteminin zorluklarını ve öğretmen görüşlerini incelemişlerdir. $\mathrm{Bu}$ çalışmada öğretmenler MOE'nin öğrencilerin problem becerilerinin gelişmesinde faydalı olduğunu belirtirken, okul matematiği ile MOE arasında zayıf bir bağın olmasını ve sınavlarda çıkan problemlere benzememesini modelleme öğretiminin negatif yönleri olarak belirtmişlerdir. Frejd (2012) çalışmasında ortaokullarda görev yapan öğretmenlerin matematiksel modelleme ile ilgili bilgi düzeylerini ve bu yöntemi uygulama deneyimlerini araştırmıştır. Öğretmenlerin bir kısmı daha önce modelleme kavramını hiç duymadıklarını belirtirken bir kısmı matematiksel modellemenin fizik ve kimya derslerinde daha çok kullanılabileceğini belirtmişlerdir. Akgün, Çiltaş, Deniz, Çiftçi ve Işı1k (2013) çalışmalarında ilköğretim matematik öğretmenlerinin matematiksel modelleme yöntemi hakkındaki görüşlerini incelemişlerdir. Çalışma sonucunda öğretmenlerin matematiksel modelleme ile ilgili yeterli bilgiye sahip olmadıkları görülmüştür. Güder (2013) çalışmasında ortaokul matematik öğretmenlerinin matematiksel modellemeye ilişkin görüşlerini incelemiştir. Çalışma sonucunda ortaokul matematik öğretmenlerinin matematiksel modellemeye ilişkin bilgi düzeylerinin yeterli olmadığı, matematiksel modelleme kullanıldığında öğrencilerin derse ilgisinin arttığı, matematiksel modellemenin programda yer alması gerektiği, konuya göre matematiksel modellemeyi oluşturmanın zorluk düzeyinin değiştiği görüşlerini tespit etmiş̧ir. Tekin Dede ve Bukova Güzel (2013)'deki çalışmalarında ortaöğretim matematik öğretmenlerinin MOE ve derslerde kullanımlarına ilişkin görüşlerini incelemişlerdir. Bu çalışmada on yedi öğretmen ile matematiksel modelleme çalıştayının öncesinde odak grup görüşmeleri yapılmıştır. Öğretmenler yapılan çalıştayda 3-4 kişilik gruplar halinde MOE'ni 
tasarlamışlardır. Tasarım süreçlerinin ardından öğretmenlerle son odak grup görüşmesi gerçekleştirilmiştir. İlk odak grup görüşmesinde öğretmenlerin MOE içerdiği kelimelerden hareketle tanımlamaya çalıştıkları, son odak grup görüşmesinde ise öğrencilerinin ilgilerini çekmek, farklı matematik konularını ya da disiplinler arası konuları bütünleştirmek gibi sebeplerle MOE'ni derslerinde kullanabileceklerini belirttikleri görülmüştür. Bilen ve Çiltaş (2015) çalışmalarında ortaokul matematik öğretmenlerinin görüşlerine göre beşinci sınıf öğretim programını matematiksel model ve modelleme açısından incelemeyi amaçlamışlardır. Öğretmenler, öğrencilerin matematiğe karşı tutumlarında, derse katılımlarında ve kavramsal öğrenmelerinde modellemenin olumlu etkisinin olduğunu vurgulamışlardır. Işık ve Mercan (2015) çalışmalarında ortaokul matematik öğretmenlerinin model ve modelleme hakkındaki görüşlerini incelemişlerdir. Araştırma sonucunda öğretmenlerin model ve modelleme ile ilgili genel bilgiye sahip olduklarını; ancak verilen örneklerden hangilerinin model olarak nitelendirilebileceği ile ilgili bilgilerinde eksikliklerin olduğunu tespit etmişlerdir. Urhan ve Dost (2016) ise çalışmalarında ortaöğretim matematik öğretmenlerinin matematiksel modelleme etkinliklerinin öğretim sürecinde kullanılmasına ilişkin görüşlerini ortaya koymayı amaçlamışlardır. Öğretmenlerin modelleme etkinliklerinin matematik öğretiminde uygulanmasında etkili olan faktörleri modelleme etkinliklerine yönelik kaynakların sınırlı olması, öğretmenlerin modelleme etkinlikleri konusundaki eksikliği ve öğrencilerin hazırbulunuşluk düzeyleri şeklinde belirttikleri görülmüştür.

Literatürde var olan çalışmalara bakıldığında öğretmenlerin matematiksel modellemeye yönelik görüşlerinin incelendiği birçok çalışmanın olduğu görülmektedir. Ancak bu çalışmaların hiçbirinde öğretmenlerin bireysel olarak MOE tasarlamaları ve bu etkinlikleri sınıflarına uygulamaları öncesi ve sonrasındaki görüşleri ayrıntılı bir şekilde incelenmemiştir. Bu çalışmada ön görüşmelerle öğretmenlerin matematiksel modelleme ile ilgili görüşleri herhangi bir uygulama yapılmadan tespit edilmeye çalışılmıştır. Son görüşmelerle ise uygulama süreci sonunda öğretmenlerin modelleme yöntemi, MOE'nin tasarlanması ve MOE’ni sınıf uygulamalarındaki deneyimlerine ilişkin görüşleri tespit edilmeye çalışılmıştır. Ayrıca öğretmenlerin matematiksel modellemeye ilişkin görüşlerinde ne gibi değişikliklerin olduğu da tespit edilmeye çalışılmıştır.

\section{YÖNTEM}

\subsection{Araştırma Deseni}

$\mathrm{Bu}$ çalışmada ortaöğretim matematik öğretmenlerinin matematiksel modelleme yöntemine ve bu yöntemin sınıflarda uygulanmasına yönelik görüşlerinin tespit edilmesi amaçlanmıştır. Dolayısıyla araştırmada nitel araştırma yöntemlerinden olgu bilim deseni esas alınmıştır. Çünkü olgu bilimde bir olgu hakkında derinlemesine bilgi sahibi olmak ve bireylerin bu olgu ile ilgili yaşadıkları deneyimleri ortaya koymak amaçlanmaktadır. Olgu bilimde yaşantılar, yaşantıların geçtiği ortam ve çalışılan olguyu ortaya çıkarmak önemlidir (Metin, 2014). 


\section{2. Çalışma Grubu}

Araştırma, Ağrı il merkezinde görev yapan 13 matematik öğretmeni ile yürütülmüştür. Katılımcıların belirlenmesinde amaçlı örnekleme yöntemleri içinde yer alan kolay ulaşılabilir örnekleme tekniği kullanılmıştır. Kolay ulaşılabilir örneklem, yakın ve erişilmesi kolay olan durumun seçilmesidir. Kolay ulaşılabilir örneklemler göreli olarak daha az maliyetlidir ve bazı araştırmacılar için pratik ve kolay olarak algılanabilir (Yıldırım ve Şimşek, 2008). Görüşme yapılan öğretmenler gönüllüllük esasına dayalı olarak belirlenmiştir. Araştırmaya katılan öğretmenlerin dokuzu Anadolu Lisesi, biri Fen Lisesi, ikisi Anadolu İmam Hatip Lisesi ve biri Anadolu Endüstri Meslek Lisesinde görev yapmaktadır. Bu öğretmenlerden sadece biri lisans eğitiminde matematiksel modelleme yöntemine yönelik bir ders almıştır. Araştırmaya katılan öğretmenler Ö1, Ö2..., Ö13 şeklinde kodlanarak çalışmada isimlerine yer verilmemiştir.

\subsection{Veri Toplama Araçları ve Verilerin Toplanması}

Araştırmada veri toplama araçları olarak öğretmenlerin matematiksel modelleme yöntemi ve bu yöntemin uygulanmasına yönelik görüşlerini tespit etmek amacıyla yarı yapılandırılmış ön görüşme formu ve son görüşme formu kullanılmıştır. Görüşme sorularının hazırlanmasında Lingefjärd (2007), Özer Keskin (2008), Aydın (2008), Özturan Sağırlı (2010), Doruk (2010), Çiltaş (2011) ve Akgün vd. (2013) çalışmalarında yer alan görüşme sorularından faydalanılmıştır. Ön görüşme formunda ortaöğretim matematik öğretmenlerinin matematiksel modellemeye ilişkin ön bilgilerinin ne düzeyde olduğu tespit edilmeye çalışılırken son görüşme formunda tasarlanan etkinliklerin uygulanması sonunda öğretmenlerin matematiksel modelleme yöntemi ve bu yöntemin uygulanma süreciyle ilgili düşünceleri tespit edilmeye çalışılmıştır. Görüşme formları pilot çalışma sonrasında yeniden düzenlenip son hallerini almıştır. Pilot çalışma ortaöğretim matematik öğretmeni adaylarından "Öğretmenlik Uygulaması" dersini alan altı öğretmen adayı ile gerçekleştirilmiştir. İlk olarak beş hafta boyunca matematiksel modelleme yöntemi tanıtılmıştır. Sonrasında her hafta en az iki öğretmen adayının MOE tasarlamaları ve bunları staj okullarında uygulamaları kararlaştırılmıştır. Öğretmen adayları matematiksel modelleme yöntemini içeren ikişer adet MOE hazırlamışlardır ve bunları staj okullarında uygulamışlardır. Öğretmen adaylarının süreç sonunda matematiksel modelleme ile ilgili bilgi düzeylerini belirlemek ve uygulama sürecini kapsamlı bir şekilde değerlendirmelerini sağlamak amacıyla uygulama sürecinin sonunda öğretmen adayları ile matematiksel modelleme ile ilgili görüşmeler yapılmıştır. Elde edilen bulgular matematiksel modelleme ile ilgili çalışmaları olan iki uzman ile paylaşılmış ve bu yöntemi sınıflarında uygulayacakların öğretmenlerin olacağı düşünülmüş ve esas çalışmada öğretmen adayları yerine öğretmenlerin modelleme ile ilgili bilgi ve deneyimlerinin incelenmesinin çok daha gerçekçi sonuçlar vereceği düşünülmüştür. Ayrıca bu süreçte görüşme formları test edilmiş, yeterli bilgi toplayamayan maddeler çıkarılmış, eksiklikler tamamlanmış ve bu formlar yeniden düzenlenmiştir.

Uygulama Ağrı il merkezinde görev yapan ortaöğretim matematik öğretmenleriyle yürütülmüştür. Uygulamaya başlamadan önce Ağrı İl Milli Eğitim Müdürlüğünden 
gerekli izinler alınmıştır. Çalışmaya katılmak isteyen öğretmenler belirlenip bu öğretmenlerle ön görüşmeler yapılmıştır. Ön görüşmelerden sonra bu öğretmenlere yaklaşık bir ay MOE tasarım prensipleri ve matematiksel modelleme yöntemi ile ilgili gerekli bilgiler verilmiştir. $\mathrm{Bu}$ süreçte matematiksel modelleme yöntemi çalışma grubundaki aynı okulda görev yapan öğretmenlere haftanın belirli günlerinde, farklı okullarda görev yapan öğretmenlere ise uygun oldukları boş vakitlerde tanıtılmıştır. Çalışmanın başında çalışmaya katılmak isteyen bazı öğretmenler MOE'ni tasarlamada sorun yaşayabileceklerini belirterek çalışmadan ayrılmışlardır. Çalışmaya devam etmek isteyen öğretmenlere herhangi bir nedenden dolayı çalışmaya devam etmek istemediklerinde yarıda bırakmakta serbest oldukları belirtilmiştir. Öğretmenler MOE tasarım prensiplerini dikkate alarak iki dönem boyunca toplamda 49 etkinlik tasarlamışlardır ve tasarladıkları bu etkinliklerin hangi konularla ilgili olacağını kendileri belirlemişlerdir. Uygulama sürecinde öğrencilerin gruplar ve sınıf düzeni öğretmenler tarafından oluşturulmuş, araştırmacının hiçbir müdahalesi olmamıştır. Sürecin sonunda öğretmenler ile matematiksel modelleme ve uygulama süreci ile ilgili görüşmeler yapılmıştır.

\subsection{Verilerin Analizi}

Ortaöğretim matematik öğretmenlerinin matematiksel modelleme yöntemine ve bu yöntemin sınıf içi uygulamalarına yönelik görüşlerini tespit etmek amacıyla yapılan görüşmelerden elde edilen veriler içerik analizi ile analiz edilmiştir. Elde edilen veriler uygulama sürecinin sonunda transkript edilmiştir, kategori, kod ve frekans listesi oluşturulmuştur. Görüşmelerden elde edilen verilerin güvenirlik analizi amaciyla seçilen transkriptler, bu transkriptlerin analizi sonucunda oluşturulan kategoriler ve kodlar, aradan zaman geçtikten sonra araştırmacı tarafından tekrar kodlanmış ve kodlama güvenirliği \%90 olarak belirlenmiştir. Ayrıca oluşturulan bu kod ve kategoriler bir uzman tarafından da incelenmiş ve araştırmacının elde ettiği kodlarla karşılaştırılmıştır. Oluşturulan kategori-kod listesindeki bazı kodlarda değişiklikler yapılmıştır. Çalışmada araştırmacı ve uzmanın belirlediği kategoriler ve kodların güvenilirlik hesaplamasına yönelik Miles ve Huberman'ın (1994) önerdiği hesaplama yöntemi kullanılmıştır. Bu hesaplamaya göre;

$$
\text { Güvenirlik Formülü }=\left(\frac{\text { Görüş Birliği }}{\text { Görüş Birliği+ Görüş Ayrılığı }}\right) \times 100
$$

şeklindedir. Miles ve Huberman'ın (1994) uyuşum yüzdesi formülü ile yapılan hesaplamanın sonucunda görüşmelerde belirlenen kodlara ait güvenirlik yaklaşı \% $\% 8$ olarak hesaplanmıştır.

\section{BULGULAR}

Öğretmenlerle yapılan ön görüşmelerden matematik eğitiminde gerçek hayat problemlerinden faydalanılmasına ilişkin elde edilen kategori, kod ve frekanslara Tablo 1 'de yer verilmiştir. 
Tablo 1. Öğretmenlerle Yapılan Ön Görüşmelerde Matematik Eğitiminde Gerçek Hayat Problemlerinden Faydalanılmasına İlişkin Görüşlere Ait Kategori, Kod ve Frekans Tablosu

\begin{tabular}{llc}
\hline Kategori & Kod & $\mathrm{f}$ \\
\hline & Matematiğin gerçek hayattaki kullanışlılı̆̆ını anlama & 6 \\
Matematik Eğitiminde & İlgi çekici olma & 3 \\
Gerçek Hayat & Somutlaştırmayı sağlama & 3 \\
Problemlerinden & Her konuya uygun gerçek hayattan örnek bulamama & 3 \\
Faydalanılması & Motive edici olma & 3 \\
& Kalıcı öğrenmeyi sağlama & 2 \\
& Kolay anlaşılır olma & 2 \\
\hline
\end{tabular}

Matematiksel modellemenin temelinde gerçek hayat problemleri vardır. Bu yüzden ilk olarak ögretmenlerin matematik eğitiminde gerçek hayat problemlerinden faydalanılması ile ilgili görüşleri tespit edilmeye çalışılmıştır. Yapılan görüşmede öğretmenlerin matematik eğitiminde gerçek hayat problemlerinden faydalanılmasına ilişkin düşünceleri "matematiğin gerçek hayattaki kullanışlılığını anlama, ilgi çekici olma, somutlaştırmayı sağlama, kalıcı öğrenmeyi sağlama, motive edici olma, her konuya uygun gerçek hayattan örnek bulamama ve kolay anlaşılır olma şeklinde kodlanmıştır.

Gerçek hayat problemlerine derslerde yer verilmesi ile ilgili olarak matematiğin gerçek hayattaki kullanışlılığının anlaşılması, öğrencilerin matematik dersine olan ilgisinin artması, kalıcı öğrenmenin sağlanması ve öğrencilerin motive olmasına yönelik Ö̈'nin düşünceleri şöyledir:

"Matematik eğitiminde gerçek hayat problemlerinden kesinlikle faydalanılmalıdır. Çünkü neredeyse her derste bir tane ögrenci çıkıyor hocam diyor bu problemler gerçek hayatta ne işimize yarayacak, yani nerede kullanacă̆ız. Biz de bazı konularda hiçbir şey diyemiyoruz. Gerçek hayattan örnekler verdiğimiz zaman ögrencilerin daha çok hoşuna gidiyor bunlar, daha çok ögrenme isteği duyuyorlar. Ama gerçek hayattan örnek veremediğimiz zaman sadece sinava yönelik çalıştıkları için tam ögrenemiyorlar, unutuyorlar."

Matematik derslerinde gerçek hayat problemlerine yer verilmesi ile matematiğin somut hale geldiğine ve konuların kolay anlaşılır olmasına yönelik Ö2'nin düşünceleri şöyledir:

"Hayatla ilgili öğrencilerimiz tahtada gördüğü şekli günlük hayata hani somutlaştırma diyelim, aslında matematiği daha iyi ögrenir ve ögrenmek için daha iyi çaba sarf eder."

Elde edilen bulgulara göre öğretmenlerin hepsi derslerinde gerçek hayat problemlerinden faydalanılmasını olumlu bulmaktadırlar.

Öğretmenlerle yapılan ön ve son görüşmelerden matematiksel model kavramına ilişkin elde edilen kategori, kod ve frekanslara Tablo 2'de yer verilmiştir. 
Tablo 2. Öğretmenlerle Yapılan Ön ve Son Görüşmelerde "Matematiksel Model” Kavramına İlişkin Görüşlere Ait Kategori, Kod ve Frekans Tablosu

\begin{tabular}{lllr}
\hline Görüşmeler & Kategori & Kod & $\mathrm{f}$ \\
\hline \multirow{3}{*}{ Ön Görüşme } & & Somut materyal & 5 \\
& & Günlük hayat problemlerinin matematiksel & 4 \\
& Matematiksel & çözümü & \\
& & Bilgim yok & 3 \\
& Model & Formüller ve şekiller & 1 \\
\cline { 3 - 4 } Son Görüşme & Cebirsel Gösterim (eşitlik, denklem, formül) & 7 \\
& & Grafik & 6 \\
& & Şekil & 3 \\
& & Tablo & 1 \\
\hline
\end{tabular}

Yapılan görüşmede öğretmenlerin matematiksel model kavramının ne olduğuna ilişkin düşünceleri ön görüşmelerde bilgim yok, somut materyal, günlük hayat problemlerinin matematiksel çözümü ve formüller ve şekiller şeklinde kodlanmıştır. Bu kodların frekanslarına bakıldığında üç öğretmenin daha önce matematiksel model kavramını duymadığı ve öğretmenlerin çoğunun matematiksel modeli somut materyal olarak düşündüğü görülmektedir. Dört öğretmen matematiksel modeli günlük hayat problemlerinin matematiksel çözümü şeklinde düşünüp matematiksel model yerine matematiksel modellemeyi tanımlamıştır. Sadece bir öğretmenin matematiksel modeli doğru bir şekilde bildiği görülmektedir. Öğretmenlerin son görüşmelerdeki matematiksel model kavramının ne olduğuna ilişkin görüşleri ise cebirsel (eşitlik, denklem, formül) gösterim, grafik, şekil ve tablo şeklinde kodlanmıştır.

Matematiksel modelin somut materyal olduğuna yönelik Ö11 ön görüşmelerde şunları belirtmiştir:
"Matematiksel modeller yani bir polinomlarda çarpma işlemini mesela dikdörtgenin ya da karenin alanından çıkarabilmek ya da şey elinize bir şey alırsınız karton falan, bunları şekle dökersiniz...”

Öğretmenlerin bazıları matematiksel modeli tanımlarken farkında olmadan matematiksel modellemeyi ifade etmişlerdir. Örneğin ön görüşmelerde matematiksel modelin günlük hayat problemlerinin matematiksel çözümü olduğuna yönelik Ö4’ün düşünceleri şu şekildedir:
"Aslında hayatın her noktası matematik olduğu için günlük hayattaki bir durumu matematiksel olarak sembolleme ya da matematiksel dile çevirme anlaminda."

Ön görüşmelerde matematiksel model kavramını daha önce duymadığı için bu konuda bilgisinin olmadığını, ancak matematiksel modelin grafik, desen olabileceğini tahmin eden Ö9'un düşünceleri şu şekildedir:

"Yani açıkçası hiç duymadım ama ben şu anda aklımdaki şeylerin bunlarla alakasız olduğunu düşünüyorum. İlk çağrışım yapan şeyi söyleyeyim. Bizim hani modellerle ilgili bir konumuz var, daha çok grafik, desen üzerine; ilk aklıma gelen o ama ne bileyim. 10. sinif geometrisinde desen ve model oluşturma bölümü var, oralarda sadece o geliyor aklıma." 
Ön görüşmelerde matematiksel modelin formüller ve şekiller olduğuna yönelik Ö2'nin düşünceleri şu şekildedir:

"Matematiksel model bizim kitaplarda gördügümüz formüller, şekillerdir."

Son görü̈smelere incelendiğinde ise matematiksel modelin grafik ve cebirsel gösterim olduğuna yönelik Ö4'ün düşüncesi şu şekildedir:

"Matematiksel model matematiksel işlemleri kullanırken yararlandığımız eşitlik, denklik, büyük eşit, küçük eşit, grafikler, çeşitli sembollerdir."

Ön görüşmelerde matematiksel modelleri somut materyaller olarak düşünen Ö11, son görüşmede matematiksel modelleri formüller ve terimler olarak tanımlamıştır. Ö11'in matematiksel modele ilişkin son görüşmedeki düşünceleri ise şöyledir:

"Matematiksel model formüller, işte çeşitli terimler, bunların hepsi genel olarak matematiksel model olarak ifade edilir."

Ön görüşmelerdeki yanıtlara bakıldığında öğretmenlerin matematiksel modelleri daha çok somut modeller ve günlük hayat problemlerinin matematiksel çözümü olarak ifade ettikleri görülmektedir. Ancak son görüşmelere bakıldığında bu öğretmenlerin matematiksel modelleri tablo, şekil, grafik, denklem, eşitlik şeklinde belirttikleri görülmektedir. Dolayısıyla öğretmenlerin matematiksel modellere yönelik düşüncelerinde değişim meydana geldiğini söyleyebiliriz.

Öğretmenlerle yapılan ön ve son görüşmelerden matematiksel modelleme kavramına ilişkin elde edilen kategori, kod ve frekanslara Tablo 3 'te yer verilmiştir.

Tablo 3. Öğretmenlerle Yapılan Ön ve Son Görüşmelerde "Matematiksel Modelleme" Kavramına İlişkin Görüşlere Ait Kategori, Kod ve Frekans Tablosu

\begin{tabular}{lllc}
\hline Görüşmeler & Kategori & Kod & $\mathrm{f}$ \\
\hline \multirow{3}{*}{ Ön Görüşme } & & Matematik ile günlük hayat arasında ilişki kurma & 6 \\
& Matematiksel & Somut materyal hazırlama ve kullanma & 4 \\
\cline { 3 - 4 } Son Görüşme & Modelleme & Bilgim yok & 3 \\
\cline { 3 - 4 } & & Günlük hayat problemlerinin matematiksel çözümü & 11 \\
& & Model oluşturma & 2 \\
\hline
\end{tabular}

Yapılan görüşmede öğretmenlerin matematiksel modelleme kavramının ne olduğuna ilişkin düşünceleri ön görüşmelerde bilgim yok, somut materyal hazırlama ve kullanma ve matematik ile günlük hayat arasında ilişki kurma, son görüşmelerde ise günlük hayat problemlerinin matematiksel çözümü ve matematiksel model oluşturma şeklinde kodlanmıştır. Tablo 3'e bakıldığında öğretmenlerin çoğunun ön ve son görüşmelerde matematiksel modellemeyi matematik ile günlük hayat arasında ilişki kurma şeklinde düşündüğ̈̈ görülmektedir.

Matematiksel modellemenin matematik ile günlük hayat arasında ilişki kurmak olduğuna yönelik Ö6'nın ön görüşmelerdeki düşüncesi şu şekildedir:

“Bana göre matematiksel modelleme matematik ile gerçek hayatla ilişkisini kurma işidir." 
Ön görüşmelerde matematiksel modellemeyi somut materyal hazırlama ve kullanma şeklinde düşünen Ö11 şunları belirtmiştir:

"Matematiksel modeller yani bir polinomlarda çarpma işlemini mesela dikdörtgenin ya da karenin alanından çıkarabilmek ya da şey elinize bir şey alırsinız karton falan, bunları şekle dökersiniz..."

Ön görüşmelerde matematiksel modellemeyi somut materyal yapma işi olarak düşünen Ö11, son görüşmede matematiksel modellemeyi günlük hayat problemlerinin matematik dilinde ifade edilip sonra tekrar yorumlanması olarak belirtmiştir. Dolayısıyla başlangıçta matematiksel modellemeyi somut materyal yapma işi olarak düşünen Ö11'in matematiksel modellemeye yönelik düşüncelerinde değişim meydana gelmiştir. Ö11'in matematiksel modele ilişkin son görüşmedeki düşünceleri şöyledir:

"Matematiksel modelleme de günlük hayat problemlerinin matematik dilinde ifade edilip sonra tekrar yorumlanmast. Yani matematiksel olarak çözme."

Öğretmenlerle yapılan son görüşmelerden matematiksel modelleme sürecinde izlenen yola ilişsin elde edilen kategori, kod ve frekanslara Tablo 4'te yer verilmiştir.

Tablo 4. Öğretmenlerle Yapılan Son Görüşmelerde Matematiksel Modelleme Sürecinde İzlenen Yola İlişkin Görüşlere Ait Kategori, Kod ve Frekans Tablosu

\begin{tabular}{lll}
\hline Kategori & Kod & $\mathrm{f}$ \\
\hline Matematiksel Modelleme Sürecinde & Matematiksel modelleme adımlarının & 10 \\
İzlenen Yol & uygulanması & \\
& Model oluşturma aşaması & 3 \\
\hline
\end{tabular}

Öğretmenlerin matematiksel modelleme sürecinde izlenen yola ilişkin görüşleri matematiksel modelleme adımlarının uygulanması ve model oluşturma aşaması şeklinde kodlanmıştır.

Matematiksel modelleme sürecinde izlenen yolun matematiksel modelleme adımlarının uygulanması şeklinde olduğunu düşünen Ö10'in düşüncesi şu şekildedir:

"İlk önce bu problemin gerçek hayattaki durumuna bakarım. Gerçek hayatta bizim hangi sıkıntımızı giderebilir, hangi işimizi kolaylaştırır. Ondan sonra problemi anlamaya çalışırım, problemi anladıktan sonra gerçek hayattan bir değişken seçmeye çalışırım denklem kurarken, değişkenin ne olacă̆ını belirlemeye çalışırım. Ondan sonra buna göre matematiksel modele göre bir plan kurarım ona göre bir denklem oluştururum, sonra matematiksel modeli oluşturduktan sonra bu modeli çözmeye çalışırım, çözdükten sonra da bunun doğruluğunu kontrol ederim. Daha sonra da gerçek hayata yorumlarım."

Matematiksel modelleme sürecinde izlenen yolun sadece model oluşturma aşaması olduğunu düşünen Ö1'in düşüncesi şu şekildedir: 
"Ĕger direkt yapabileceğimiz bir soru ise direkt çözüyoruz zaten ama bir formülü ya da başka bir şeyi yoksa önce normal bildiğimiz bilgiler ışı̆̆ında formül oluşturuyoruz."

Ö10 yukarıdaki açıklamasında modelleme sürecinin tüm aşamalarını eksiksiz olarak belirtirken, Ö1 modelleme sürecinin sadece model oluşturma aşaması olduğunu belirtmiştir.

Öğretmenlerle yapılan ön görüşmelerden matematiksel modellemenin derslerde kullanılma durumlarına ilişkin elde edilen kategori, kod ve frekanslara Tablo 5'te yer verilmiştir.

Tablo 5. Öğretmenlerle Yapılan Ön Görüşmelerde Matematiksel Modellemeyi Derslerde Kullanma Durumlarına İlişkin Görüşlere Ait Kategori, Kod ve Frekans Tablosu

\begin{tabular}{lll}
\hline Kategori & Kod & $\mathrm{f}$ \\
\hline \multirow{2}{*}{ Matematiksel Modellemeyi Derslerde Kullanma } & Kullanmiyorum & 8 \\
& Kullanıyorum & 5 \\
\hline
\end{tabular}

Öğretmenlerin derslerinde matematiksel modelleme yöntemini kullanma durumları kullanıyorum ve kullanmıyorum şeklinde kodlanmıştır. Tablo 5'te yer alan kodlara ilişkin frekanslara bakıldığında, matematiksel modelleme yöntemini kullanmadıklarını belirten öğretmenlerin kullandıklarını belirtenlerden daha fazla olduğu görülmektedir. Matematiksel modelleme yöntemini kullandıklarını belirten öğretmenlerden birer örnek vermeleri istenmiştir. Verilen örnekler incelendiğinde öğretmenlerden bazılarının modelleri kullandıkları ancak matematiksel modelleme yöntemini kullanmadıkları görülmüştür. Bununla ilgili olarak Ö12'nin vermiş olduğu örnek aşağıdaki gibidir:

"Modelleme yönteminde materyal kullanmaya evet çalıştım. Özellikle bir konu hazırlayarak örneğin bir parabol üzerinden materyal anlatırken parabolle işte parabolün kollarının katsayiya göre açılıp kapanmasına dair bunlarla ilgili bir çalı̧̧ma yaptık öğrencilerle."

Öğretmenlerle yapılan ön görüşmelerden matematiksel modelleme yönteminin derslerde hangi amaçlarla kullanılabileceğine yönelik elde edilen kategori, kod ve frekanslara Tablo 6'da yer verilmiştir.

Tablo 6. Öğretmenlerle Yapılan Ön Görüşmelerde Matematiksel Modellemeyi Kullanma Amaçlarına İlişkin Görüşlere Ait Kategori, Kod ve Frekans Tablosu

\begin{tabular}{lll}
\hline Kategori & Kod & f \\
\hline & Somutlaştırma & 3 \\
& Matematiğin günlük hayattaki önemini & 3 \\
Matematiksel Modellemeyi & vurgulama & \\
Kullanma Amaçları & Öğrencileri motive etme & 2 \\
& Aktif katılım & 2 \\
& Başarıyı arttırma & 2 \\
& Dikkat çekme & 1 \\
\hline
\end{tabular}


Ön görüşmelerde derslerinde matematiksel modelleme yöntemini kullanan öğretmenlere hangi amaçlarla kullandıkları sorulmuştur ve elde edilen veriler analizi edilip "somutlaştırma, matematiğin günlük hayattaki önemini vurgulama, öğrencileri motive etme, aktif katılım, başarıyı arttırma ve dikkat çekme şeklinde kodlanmıştır. Tablo 6'da yer alan kodların frekanslarına bakıldığında somutlaştırma ve matematiğin günlük hayattaki önemini vurgulamanın öne çıktığını söyleyebiliriz.

Matematiksel modelleme yöntemini kullanma amacının somutlaştırma olduğuna ilişkin Ö12 şunları belirtmiştir:

"Mesela karşıdaki öğrencinin gerçekten anlamasını kolaylaştırmak için örneğin bir parabol üzerinden materyal hazırlayalım. Materyale göre o parabolün kollarının yönü katsayısına göre değişir, kollarının açılması, kapanması ile ilgili ilk başta somut bir şey oluyor..."

Matematiksel modelleme yöntemini öğrencileri motive etme ve matematiğin günlük hayattaki önemini vurgulama amacıyla kullanan Ö5 şunları belirtmiştir:

“Öğrenciyi dersin içine sokma, günlük hayattan örneklendirme yaparak dersi anlatma öğrencinin belki matematiğe olan bakış açısını değiştirir, her şeyde matematiğin aslında var olduğunu öğrenir. Belki işin içerisine biraz daha isteyerek girer, korkarak değil. Belki biz bunu yapmadı̆̆ımız için sadece $x$, y, z'lerle çocukları meşgul ettiğimiz için çocuklar biraz matematiğe karşı soğudular."

Öğretmenlerle yapılan ön görüşmelerden derslerde matematiksel modelleme yönteminin kullanılmamasının nedenlerine ilişkin elde edilen kategori, kod ve frekanslara Tablo 7 'de yer verilmiştir.

Tablo 7. Öğretmenlerle Yapılan Ön Görüşmelerde Matematiksel Modelleme Yönteminin Kullanılmamasının Nedenlerine İlişkin Görüşlere Ait Kategori, Kod ve Frekans Tablosu

\begin{tabular}{lll}
\hline Kategori & Kod & $\mathrm{f}$ \\
\hline \multirow{2}{*}{ Matematiksel Modelleme } & Sınavlarda çıkan problemlere benzememe & 4 \\
Yönteminin Kullanılmamasının & Modellemenin ne olduğunu bilmeme & 3 \\
Nedenleri & Zaman alıcı olma & 1 \\
& Öğrenciler alışkın değil & 1 \\
\hline
\end{tabular}

Görüşmelere katılan öğretmenlerin derslerinde matematiksel modelleme yöntemini kullanmama nedenlerine ilişkin modellemenin ne olduğunu bilmeme, sınavlarda çıkan problemlere benzememe, zaman alıcı olma ve ögrenciler alışkın değil şeklinde kodlanmıştır.

Matematiksel modelleme yönteminin ne olduğunu bilmediği için derslerinde kullanmadığını belirten Ö8'in düşünceleri şöyledir:

"Yani duymadığım için bir şey diyemeyeceğim. Belki kullanıyoruzdur yani belki ismi bize yabancıdır." 
Matematiksel modelleme yönteminin zaman alıcı olmasından, öğrencilerin grup çalışmasına ve model oluşturmaya alışkın olmamasından dolayı derslerinde kullanamadığını belirten Ö4'ün düşünceleri şöyledir:

"Modelleme için çocukların altyapısı önemli, çünkü ilkokuldan itibaren çocuk dersin içinde gruplaşarak bir model ya da bir soru çözümüne alışmamış. Dolayısıyla hem de süre kaybımız çok oluyor. Yani çocuklar modellemeyi problemin çözüm basamaklarında birbirlerine olan yardımları, onlarda da biraz sıkıntımız olduğu için çok fazla vakit kaybı."

Matematiksel modelleme etkinliklerindeki problemlerin sınavlarda çıkan problemlere benzememesinden dolayı bu yöntemi kullanmadığını belirten Ö11'in düşünceleri şöyledir:

"Yani kullanmamamızın sebebini ben biraz sinav sistemine bağglyorum çünkü öğrenciyi biz test tekniğine alıştıryoruz, alıştırmak zorundayız çünkü SBS'den geçiyor bu ögrrenci ve test, LYS'ye gireceksiniz önüne yazll sinav koyuyoruz o yüzden ben pratiğe yönelik, daha çok çalışmanın mantıklı olduğunu düşünüyorum."

Öğretmenlerle yapılan son görüşmelerden etkinlikleri tasarlarken karşılaşılan sorunlara ilişkin elde edilen kategori, kod ve frekanslara Tablo 8'de yer verilmiştir.

Tablo 8. Öğretmenlerle Yapılan Son Görüşmelerde MOE’ni Tasarlarken Karşılaşllan Sorunlara İlişkin Görüşlere Ait Kategori, Kod ve Frekans Tablosu

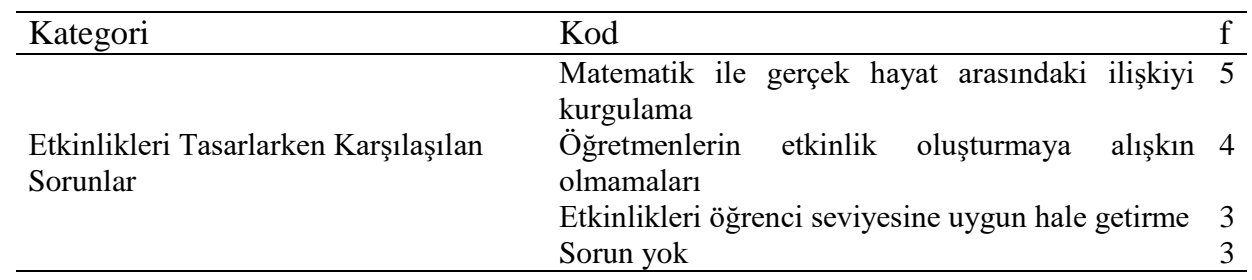

Öğretmenlerle yapılan görüşmede matematiksel modelleme yöntemini içeren etkinlikleri oluşturma sürecinde karşılaştıkları sorunlara ilişkin görüşleri matematik ile gerçek hayat arasindaki ilişkiyi kurgulama, ögretmenlerin etkinlik oluşturmaya alışkın olmamaları, ögrenci seviyesine uygun hale getirme ve sorun yok şeklinde kodlanmıştır. Tablo 8'e bakıldığında öğretmenlerin en çok matematik ile gerçek hayat arasındaki ilişkiyi kurgulamada sorun yaşadıkları görülmektedir.

Etkinlikleri oluştururken matematik ile gerçek hayat arasındaki ilişkiyi kurgulamada sorun yaşadığını belirten Ö7'nin düşünceleri şöyledir:

"Günlük hayata kendim de indirgeyemedim. Nasıl yapıldı̆̆ını, neleri kullanabilirim tarzinda. Biraz daha fazla örnek olsa iyi olur diye düşündüm."

Etkinlikleri tasarlarken öğretmenlerin etkinlik oluşturmaya alışkın olmamalarının bir sorun olduğunu belirten Ö6'nın düşünceleri şöyledir: 
"Tabi yani özellikle tasarlama ve uygulanabilirliğinde daha öncesinden bu tarz şeylerle uğraşmadı̆̆ım için, yani uğraşmadım derken çok yabancı kaldığım için sürecin nasıl işleyeceği konusunda bir fikir sahibi değildim ve tasarlama aşamasında da dediğim gibi nasıl bir şekilde hazırlayabileceğimi ilk etapta bir bocalama evresi geçirdim."

Etkinliklerin öğrenci seviyesine uygun hale getirilmesi sorununu belirten Ö4'ün düşünceleri şöyledir:

"Tabii ki yani, deneyim de çok fazla gerekti etkinlikleri tasarlarken tabii ki ögrenci seviyesine indirme, sayllarl, verileri belli bir modele göre uyarlayabilme, bazen yuvarlamalar yaptık bazen düzenlemeler yaptık.”

Öğretmenlerle yapılan ön ve son görüşmelerden matematiksel modelleme sürecinde karşılaşılan sorunlara ilişkin elde edilen kategori, kod ve frekanslara Tablo 9'da yer verilmiştir.

Tablo 9. Öğretmenlerle Yapılan Ön ve Son Görüşmelerde Matematiksel Modellemenin Uygulanma Sürecinde Karşılaşılan Sorunlara İlişkin Görüşlere Ait Kategori, Kod ve Frekans Tablosu

\begin{tabular}{llll}
\hline Görüşmeler & Kategori & Kod & f \\
\hline \multirow{4}{*}{ Ön Görüşmeler } & & Öğrenciler alışkıı değil & 3 \\
& Matematiksel & Sınavlarda çıan problemlere benzememe & 2 \\
& Modellemenin & Öğretmenin matematik ile gerçek hayat arasında & 2 \\
\cline { 3 - 4 } & Uygulanma & bağlantı kuramaması & 8 \\
\cline { 3 - 4 } Son Görüşmeler & Sürecinde & Zaman alıcı & 7 \\
& Karşılaşılan & Ögrencilerin alışkın olmaması & 4 \\
& Sorunlar & Grup çalışmasının yapılması & 3 \\
& & Öğrencilerin hazırbulunuşluklarının olmaması & 3 \\
& & Sinavlarda çıan problemlere benzememesi & 1 \\
\hline
\end{tabular}

Matematiksel modelleme yönteminin okullarda uygulanmasında karşılaşılan sorunlar ön görüşmelerde ögrrencilerin alışkın olmaması, sınavlarda çıkan problemlere benzememe ve ögretmenin matematik ile gerçek hayat arasında bă̆lantı kuramaması şeklinde kodlanmıştır. Son görüşmelerde ise zaman alıcı olması, öğrencilerin alışkın değil, grup çalışmasının yapılması, öğrencilerin hazırbulunuşluklarının yeterli olmaması, sınavlarda çıkan problemlere benzememesi ve sorun yok kodları bulunmaktadır.

Ön görüşmelerde matematiksel modelleme sürecinde yaşanan sorunlar arasında öğrencilerin bu yönteme alışkın olmamasını ve bu problemlerin sınavlarda çıkan problemlere benzemediğini belirten Ö12'nin düşünceleri şöyledir:

"Mesela ögrenciler böyle bir matematiksel modellemeye dair öncesinden bilgileri olmadığı için hani ilk başta bunu anlatmam gerekiyor... Bu sefer konu çok dallanıp budaklanıyor, sınıf ortamında çok fazla gürültüler olabiliyor, kopukluk olabiliyor. Biz yapmaya çalıştık devam etmedi. Bunun arkası gelmedi, yani şöyle gelmedi: ÖSS, YGS, LYS gerçeğini çocuklar göz önüne aldığında hocam bu bir vakit kaybıdır diyen ögrencilerimiz oldu." 
Ön görüşmelerde öğretmenlerin matematik konuları ile gerçek hayat arasında ilişki kuramadığına yönelik Ö6 ise şunları belirtmiştir:

"Modelleme sürecinde soyut konularda gerçek hayatla ilgili ilişkilendirmede biraz sorunlar yaşlyoruz ama genelde öğrenciler de bu konuda bana yardımcı olmaya çalışıorlar."

Son görüşmelerde matematiksel modellemenin çok zaman almasından, grup çalışması yapılırken sınıf yönetiminin zor olduğundan ve öğrencilerin matematiksel modelleme yöntemine alışkın olmamalarından dolayı ortaöğretim kurumlarında bu yönteminin uygulanamayacağını düşünen Ö12'nin düşünceleri şöyledir:

"ilköğretimde öğrenciler bunları görmeden, böyle modelleme üzerinden çok fazla etkinlik yaparak gelmedikleri için dersleri matematiksel modelleme yöntemi ile yaptığımız zaman neyi nereye yapacağını, nasıl yapacağını bilmiyor.... Hani nasıl yapılacağın düş̧ünüyor. Sinıfi uygun hale getirmeye çalışırken gürültü oluyor, sorun çılkyor öğrenciler arasında bir kopukluk oluyor, kargaşa oluyor..."

Okul uygulamalarında öğrencilerin hazırbulunuşluklarının yeterli olmamasının bir sorun olduğunu Ö6 şöyle belirtmiştir:

"Öğrencilerin hazırbulunuşluk düzeyi yüksek değildi, ön öğrenmeleri tam değildi ve şimdi fark ettim daha çok okuduğunu anlamaya yönelik kisımlarda bile zorluklar çektiklerini gördüm."

Öğretmenler ön görüşmelerde matematiksel modellemenin okullarda uygulanmasında karşılaşılan sorunların öğretmen, öğrenci ve sınav sisteminden kaynaklı olduğunu belirtirken, son görüşmelerde büyük oranda öğrencilerden kaynaklandığını belirtmişlerdir.

Öğretmenlerle yapılan ön ve son görüşmelerden öğretim programında matematiksel modelleme yöntemine yer verilmesine ilişkin elde edilen kategori, kod ve frekanslara Tablo 10'da yer verilmiştir.

Tablo 10. Öğretmenlerle Yapılan Ön ve Son Görüşmelerde Öğretim Programında Matematiksel Modellemeye Yer Verilmesine İlişkin Görüşlere Ait Kategori, Kod ve Frekans Tablosu

\begin{tabular}{llll}
\hline Görüşmeler & Kategori & Kod & $\mathrm{f}$ \\
\hline \multirow{2}{*}{ Ön Görüşmeler } & \multirow{2}{*}{ Öğretim Programında Matematiksel } & Yeterli & 10 \\
\cline { 3 - 4 } & Modellemeye Yer Verilmesi & Yetersiz & 3 \\
\cline { 3 - 4 } Son Görüşmeler & & Yeterli & 3 \\
& & Yetersiz & 10 \\
\hline
\end{tabular}

Görüşmelere katılan öğretmenlerin öğretim programında matematiksel modellemeye yer verilmesi gerektiğine ilişkin görüşleri yeterli ve yetersiz şeklinde kodlanmıştır. Tablo 10 'da yer alan kodların frekanslarına bakıldığında ön görüşmelerde ortaöğretim matematik dersi öğretim programında matematiksel modellemeye yer verilmesinin yeterli oluğunu düşünen öğretmenlerin sayısının son görüşmelere göre daha fazla olduğu görülmektedir. 
Öğretim programında matematiksel modellemeye yer verilmesini yetersiz bulan Ö4 ön görüşmede şunları belirtmiştir:

"Müfredatta yeterince yer verilmiyor..."

Ortaöğretim matematik öğretim programında matematiksel modellemeye yer verilmesini yeterli bulan Ö4 son görüşmesinde şunları belirtmiştir:

"Müfredat, normal hazırlanan ders programlarında yeterince var. Ancak seviyeleri hakkında bir şey söylemek gerekirse tabii ki çocukların seviyelerine ăgır etkinlikler de konulmus bence. " (Ö4)

Yapılan ön görüşmelerde Ö4 matematik öğretim programında matematiksel modellemeye yeterince yer verilmediğini belirtirken son görüşmede Ö4 matematik ögretim programında matematiksel modellemeye yeterince yer verildiğini ancak bu etkinliklerin öğrenci seviyelerine göre uygun olmadığını belirtmiştir.

Öğretmenlerle yapılan ön ve son görüşmelerden üniversitelerde verilen matematiksel modelleme eğitimine ilişkin elde edilen kategori, kod ve frekanslara Tablo 11'de yer verilmiştir.

Tablo 11. Öğretmenlerle Yapılan Ön ve Son Görüşmelerde Üniversitelerdeki Matematiksel Modelleme Eğitimine İlişkin Görüşlere Ait Kategori, Kod ve Frekans Tablosu

\begin{tabular}{lllc}
\hline Görüşmeler & Kategori & Kod & $\mathrm{f}$ \\
\hline Ön Görüşmeler & & $\begin{array}{l}\text { Uygulamaya dönük matematiksel } \\
\text { modelleme dersi olmalı }\end{array}$ & 13 \\
\cline { 3 - 4 } Son Görüşmeler & $\begin{array}{l}\text { Uatematiksel } \\
\text { Modelleme Eğitimi }\end{array}$ & $\begin{array}{l}\text { Uygulamaya dönük matematiksel } \\
\text { modelleme dersi olmalı } \\
\text { Diğer disiplinlerle iş birliğinin olması } \\
\text { gerektiği }\end{array}$ & 12 \\
\hline
\end{tabular}

Öğretmenlerin gelecekte matematik öğretmeni olacak öğretmen adaylarının matematiksel modellemeyi öğretebilmeleri ve derslerinde bu yönteme ilişkin etkinlikleri uygulayabilmeleri için üniversitelerde nasıl bir eğitim verilmesi gerektiğine ilişkin düşünceleri ön görüşmelerde uygulamaya dönük matematiksel modelleme dersi olmalı şeklinde kodlanmıştır. Son görüşmelerde ise uygulamaya dönük matematiksel modelleme dersi olmalı ve diğer disiplinlerle iş birliğinin olması gerektiği kodları yer almaktadır.

Üniversitelerde uygulamaya dönük matematiksel modelleme dersinin olması gerektiğine ilişkin Ö13 son görüşmede şunları belirtmiştir:

"Matematik öğretmeni adaylarının uygulamalı bir şekilde matematiksel modelleme derslerinin olmasl lazım. Mesela matematiksel modelleme dedik bunun teknik olarak değil uygulamalı olarak ögretmen tarafinda uygulanması lazım."

Üniversitelerde matematik öğretmenliği bölümünün diğer disiplinlerle arasında iş birliğinin olması gerektiğine ilişkin son görüşmede Ö4 şunları belirtmiştir: 
"Daha fazla diğer fakültelerle iş birliği içerisinde olunabilir. Bir biyoloji alanında bakterilerin büyümesi, üremesi gibi farkl farklı mühendisliklerde olsun alan hesaplama, ısı iletimi gibi şeylerde üniversiteler, fakülteler birbirleri ile iletişim halinde olabilir."

Yapılan görüşmelerde öğretmenlerin ağırlıklı olarak üniversitelerde uygulamaya dönük matematiksel modelleme dersinin olmasını istedikleri görülmektedir.

Öğretmenlerle yapılan son görüşmelerden uygulama sürecinin katkılarına ilişkin elde edilen kategori, kod ve frekanslara Tablo 12'de yer verilmiştir.

Tablo 12. Öğretmenlerle Yapılan Son Görüşmelerde Uygulama Sürecinin Katkılarına İlişkin Görüşlere Ait Kategori, Kod ve Frekans Tablosu

\begin{tabular}{lll}
\hline Kategori & Kod & $\mathrm{f}$ \\
\hline \multirow{2}{*}{$\begin{array}{l}\text { Uygulama } \\
\text { Sürecinin Katkıları }\end{array}$} & Matematik ile günlük hayat arasında ilişki kurma & 4 \\
\cline { 2 - 3 } & Ders anlatımını kolaylaştırma & 3 \\
\cline { 2 - 3 } & MOE'ni oluşturup uygulama & 2 \\
\hline
\end{tabular}

Öğretmenlerin matematiksel modelleme yönteminin uygulama sürecindeki katkılarına ilişkin görüşleri matematik ile günlük hayat arasında ilişki kurma, ders anlatımını kolaylaştırma, öğrencilerin düşüncelerini okuma ve matematiksel modelleme etkinliklerini oluşturup uygulama şeklinde kodlanmıştır.

Uygulama sürecinin matematik ile günlük hayat arasında ilişki kurmada katkısının olduğunu belirten Ö7'nin düşünceleri şu şekildedir:

"Bir ögretmen olarak ben de bilmiyordum mesela bunlardan nerde yararlanıyoruz, nerde kullanıyoruz, ögrenciler sorduğu zaman çok açık cevaplar veremiyoruz. Bu örnekleri gördüğ̈̈müz zaman benim için de bayağ̀ etkili olduğunu söyleyebilirim."

Uygulama sürecinin MOE'ni tasarlayıp uygulanmasına katkısının olduğunu belirten Ö4'ün düşünceleri şu şekildedir:

"Tabii ki bu süreci oluşturulurken öncelikle bazı gerekli ön bilgiler işte model, modelleme bunlarl ögrendikten sonra gerçek hayat problemine biz bu matematiksel modeli nasıl aktarırız biraz daha yani daha çok düşünmemiz gerekti. Yani bir konuyu alıp da çözmek yerine kendi sorumuzu oluşturup bu soruyu gerçek hayatla ilişkilendirdik."

Burada Ö4 uygulama süreci ile hem MOE'i tasarlayabilme hem de bu etkinlikleri uygulayabilme becerisini kazandıklarını belirtmiştir. Yani öğretmenler matematiksel modellemeye yönelik bir farkındalık kazanmışlardır.

Öğretmenlerle yapılan son görüşmelerden öğretmenlerin gelecekte derslerinde matematiksel modelleme yöntemini kullanmalarına ilişkin elde edilen kategori, kod ve frekanslara Tablo 13 'te yer verilmiştir. 
Tablo 13. Öğretmenlerle Yapılan Son Görüşmelerde Öğretmenlerin Gelecekte Derslerinde Matematiksel Modelleme Yöntemini Kullanmalarına İlişkin Görüşlere Ait Kategori, Kod ve Frekans Tablosu

\begin{tabular}{lll}
\hline Kategori & Kod & $\mathrm{f}$ \\
\hline Derslerde & Kullanmamayı düšünüyorum & 9 \\
Kullanma & Kullanmayı düşünüyorum & 4 \\
\hline
\end{tabular}

Öğretmenlere derslerinde matematiksel modelleme yöntemini kullanıp kullanmayacakları sorulduğunda elde edilen görüşler kullanmamayı düşünüyorum, ögrenci seviyesine göre kullanmayı düşünüyorum ve kullanmayı düşünmüyorum şeklinde kodlanmıştır.

Derslerinde matematiksel modelleme yöntemini her konu sonunda zaman kaldığı takdirde kullanmayı düşünen Ö9 şunları belirtmiştir:

"Her konunun sonunda böyle bir şey yapılabilir diye düşünüyorum. Çünkü gördüğ̈̈m izlenimler şu şekilde oldu: gerçekten düşündü ögrenciler ve yorum yapmaya çalıștılar en azından."

Öğrencilerinin sınava hazırlandıkları için daha fazla soru çözmeleri gerektiğini ancak matematiksel modelleme problemlerinin çok fazla zaman aldığını dolayısıyla derslerinde matematiksel modelleme yöntemini kullanmamayı düşünen Ö10 şunları belirtmiştir:

"Şu an eğer ben bunu uygularsam ögrencilere haksızlı etmiş oluyorum. Çünkü ögrenci hafta sonu dershaneye gidiyor, orda ne kadar netini arttırabilirse o kadar iyi, diğer okuldaki arkadaşlartyla yarışıyor. Matematiksel modelleme ile bir derste 3-4 tane etkinlik yapabiliyorum ama diğer türlü bir derste 20 tane soru çözebiliyorum."

Öğretmenlerin çoğu derslerinde matematiksel modelleme yöntemini kullanacaklarını belirtirken bazı öğretmenler öğrencilerinin sınava hazırlandıklarından dolayı derslerinde uygulayamayacaklarını belirtmişlerdir.

Öğretmenlerle yapılan son görüşmelerden öğretmenlerin konuyla ilgili diğer görüş ve önerilerine ilişkin elde edilen kategori, kod ve frekanslara Tablo 14'te yer verilmiştir.

Tablo 14. Öğretmenlerle Yapılan Son Görüşmelerde Öğretmenlerin Konuyla İlgili Diğer Görüş ve Önerilerine İlişkin Kategori, Kod ve Frekans Tablosu

\begin{tabular}{llr}
\hline Kategori & Kod & $\mathrm{f}$ \\
\hline Konuyla İlgili Diğer Görüş ve & Öğretmen adaylarının eğitimi & 3 \\
Öneriler & Öğretmenlere yönelik hizmet içi eğitimler verilmeli & 1 \\
\hline
\end{tabular}

Öğretmenlerin matematiksel modelleme yöntemi hakkındaki diğer görüş ve önerileri ögretmen adaylarının eğitimi ve hizmet içi eğitimler şeklinde kodlanmıştır.

Hizmet öncesi, üniversitelerde matematiksel modelleme eğitimi verilmesi gerektiğine yönelik olarak Ö9'un düşüncesi şu şekildedir:

"Verebileceğim öneri şu ögretmen olduktan sonra başlaması zor bir şey.

Öğretmen adayl iken bunun bir eğitim verilirse, matematiksel 
modellemenin, ögretmen adayları ögretmen olduğunda daha hazır hale gelecek diye düşünüyorum. Şu an ben 7 yll oldu mezun olal, 7 yll sonra yeni bir şeye alışmak beni zorluyor açıkçası."

Görev yapan öğretmenlere matematiksel modelleme yöntemiyle ilgili hizmet içi eğitimler verilmesine yönelik olarak Ö13'ün düşüncesi şu şekildedir:

"Yani seminerler vs. olabilir ya da ayrıca öğretmenlere bunun uygulamasl yaptırllabilir. Öğretmenin bence bu konudaki yeterliliklerinin de ölçülmesi lazım."

Yukarıdaki açıklamalarında öğretmenler, öğretmen adayları ve öğretmenlere yönelik matematiksel modelleme seminerlerinin uygulamalı bir şekilde verilmesi gerektiğini belirtmişlerdir.

\section{SONUÇ VE TARTIŞMA}

Ön görüşmelerde öğretmenlerin bir kısmının "matematiksel model" kavramı ile ilgili bilgilerinin olmadığını belirttikleri görülürken bazı öğretmenlerin matematiksel modelleri somut modeller olarak ifade ettikleri görülmüştür. Bazı öğretmenlerin ise günlük hayat problemlerinin matematiksel çözümü olarak düşünerek matematiksel model yerine matematiksel modellemeyi ifade ettikleri tespit edilmiştir. Akgün vd. (2013) de çalışmalarında benzer şekilde ilköğretim matematik öğretmenlerinin matematiksel modelleri somut materyaller ve görseller şeklinde düşündüklerini ve matematiksel modeli matematiksel modelleme yöntemiymiş gibi ifade ettiklerini tespit etmişlerdir. Yapılan son görüşmelerde ise öğretmenlerin matematiksel modelleri tablo, şekil, grafik, denklem, eşitlik şeklinde tanımladıkları ve matematiksel model kavramı ile ilgili düşüncelerinin ön görüşmelerdeki ifadelerine göre önemli ölçüde değişim gösterdiği görülmüştür.

Ön görüşmede öğretmenlere "matematiksel modelleme" kavramının tanımı sorulmuştur. Öğretmenlerin bir kısmının bu konuda bilgilerinin olmadığını veya somut materyal hazırlama ve kullanma şeklinde ifade ettikleri görülmüştür. Güder (2013) de yapmış olduğu çalışmada öğretmenlerin matematiksel modellemeyi; matematiksel ifadelerin somutlaştırılması, materyal kullanma çabası, matematiksel ifadelerin görselleştirilmesi şeklinde belirttiklerinden dolayı tam olarak ifade edemedikleri sonucuna varmıştır. Yapılan son görüşmelerde ise öğretmenlerin matematiksel modellemeyi matematiksel model oluşturma veya günlük hayat problemlerinin matematiksel çözümü şeklinde belirttikleri görülmüsstür. Öğretmenlerin son görüş̧melerde ön görüşmelere göre matematiksel modellemeyi daha doğru bir şekilde ifade ettiklerini söyleyebiliriz. Matematiksel modelleme ile ilgili olarak öğretmenler, öğrencilerin matematiği günlük hayattan kopuk bir ders olarak gördüklerinden dolayı bu derse karşı önyargılı olduklarını, bu sorunu çözmek amaciyla da öğretmenlerin bu yöntemi derslerinde kullanarak matematiğin günlük hayattaki önemini vurgulayabildiklerini, böylelikle öğrencilerin dikkatlerini çekerek başarıyı arttırdıklarını ve öğrencileri motive etmeyi sağladıklarını belirtmişlerdir.

Uygulamalar sonunda yapılan son görüşmelerde öğretmenler MOE hazırlanırken karşılaşılan sorunları matematik ile gerçek hayat arasındaki ilişkiyi kurgulama ve etkinlik 
oluşturmaya alışkın olmamaları şeklinde belirtmişlerdir. Öğretmenler yine son görüşmelerde etkinlikleri öğrenci seviyesine uygun hale getirmede sorun yaşadıklarını belirtmişlerdir. Bu sonuç Akgün vd. (2013) ve Urhan ve Dost (2016) çalışmalarının sonuçlarına paralellik göstermiştir.

Yapılan ön görüşmelerde öğretmenler, matematiksel modellemeyi sınıflarında uygulama sürecinde yaşadıkları sorunları öğrencilerin alışkın olmaması, matematiksel modelleme problemlerinin sınavlarda çıkan problemlere benzememesi ve öğretmenlerin matematik ile gerçek hayat arasında bağlantı kuramaması şeklinde belirtmişlerdir. Birçok çalışmada okullarda modelleme uygulamalarındaki en yaygın sorunların öğretmenlerin matematik konuları ile günlük hayat arasında ilişki kuramamalarından veya öğretmenlerin daha önceden modelleme ile ilgili tecrübelerinin az olmasından kaynaklandığı ortaya çıkmıştır (Urhan ve Dost, 2016; Yu ve Chang, 2011). Son görüşmelerde ise öğretmenler bu uygulamaların zaman alıcı olduğunu, öğrencilerin alışkın olmadığını, öğrencilerin hazırbulunuşluklarının yeterli olmadığını ve etkinliklerde yer alan problemlerin sinavlarda çıkan problemlere benzemediğini belirtmişlerdir. Ön ve son görüşmelere bakıldığında uygulama sürecinde yaşanan sorunlara ilişkin öğretmen görüşlerinin çok fazla değişmediği görülmektedir. Ancak son görüşmelerde öğretmenler, öğrencilerin hazırbulunuşluluk düzeylerinin düşük olmasının modelleme uygulamalarında önemli bir sorun olduğunu belirtmişlerdir. Birçok çalışmada da bu sonuca paralel olarak öğrencilerin matematiksel modelleme yöntemi uygulamalarına alışkın olmamalarından ya da öğrencilerin hazırbulunuşluklarının düzeylerinin yeterli olmamasından kaynaklanan sorunların yaşandığı tespit edilmiştir (Özturan Sağırlı, 2010; Urhan ve Dost, 2016; Yu ve Chang, 2011).

Matematiksel modelleme yönteminin derslerde kullanılmasına yönelik olarak son görüşmelerde bazı öğretmenler öğrenci seviyesinin durumuna göre kullanmayı düşündüklerini belirtirken bazı öğretmenler bu yöntemin çok zaman almasından dolayı derslerinde kullanmayı düşünmediklerini belirtmişlerdir. Tekin Dede ve Bukova Güzel'in (2013) çalışmalarında ortaöğretim matematik öğretmenleri, derslerinde öğrenci seviyesine uygun olan MOE'den yararlanabileceklerini ifade ederken Urhan ve Dost'un (2016) çalışmasında öğretmenler, yükseköğretime geçiş sınavında modellemeye dayalı sorulara yer verilmediği sürece, modelleme etkinliklerinin derslerde etkili biçimde kullanılamayacağını belirtmiştir.

Matematiksel modelleme okullarda uygulanamadığ müddetçe matematik öğretimine bir faydası olmayacaktır. Dolayısıyla öğretmenler ve öğretmen adaylarının bu konuda bilgi ve beceri sahibi olmaları önemlidir. Yapılan son görüşmelerde öğretmenler, belli bir süre hizmet verdikten sonra öğretmenlerin matematiksel modelleme etkinliklerine başlamasının zor olduğunu öne sürerek öğretmen adayı iken öğrenmeleri gerektiğini vurgulamışlardır. Ayrıca öğretmenlere matematiksel modelleme yönteminin hizmet içi eğitim seminerleri yardımıyla uygulamalı bir şekilde öğretilmesi gerektiğini belirtmişlerdir.

Matematiksel modelleme yönteminin istenen düzeyde uygulanabilmesi için öğretmenlerin matematiksel modellemeye yönelik farkındalıkları arttırılabilir. Ayrıca farklı düzeylerdeki öğrenciler için MOE hazırlanabilir ve bu etkinlikler bir web sayfasında paylaşılabilir. 


\section{KAYNAKÇA}

Akgün, L., Çiltaş, A., Deniz, D., Çiftçi, Z., \& Işık, A. (2013). İlköğretim Matematik Öğretmenlerinin Matematiksel Modelleme İle İlgili Farkındalıkları. Adlyaman Üniversitesi Sosyal Bilimler Enstitüsü Dergisi, 6(12), 1-34.

Antonius, S., Haines, C., Jensen, T. H., Niss, M., \& Burkhardt, H. (2007). Classroom activities and the teacher. In W. Blum, P. L. Galbraith, H. W. Henn and M. Niss (Eds.), Modelling and applications in mathematics education: 14th ICMI Study (pp. 295308). New York: Springer.

Aydın, H. (2008). Ingiltere'de Öğrenim Gören Öğrencilerin ve Öğretmenlerin Matematiksel Modelleme Kullanımına Yönelik Fenomenografik Bir Çalı̧̧ma. Yüksek Lisans Tezi. Ankara: Gazi Üniversitesi.

Baki, A. (2008). Kuramdan uygulamaya matematik eğitimi (4. Bask1). Ankara: Harf Eğitim Yayıncılı̆̆ı.

Bilen, N., \& Çiltaş, A. (2015). Ortaokul Matematik Dersi Beşinci Sınıf Öğretim Programı'nın Öğretmen Görüşlerine Göre Matematiksel Model ve Modelleme Açısından İncelemesi. e-Kafkas Eğitim Araştırmaları Dergisi, 2(2), 40-54.

Chapman, O. (2007). Mathematical modelling in high school mathematics: teachers' thinking and practice. In W. Blum, P. L. Galbraith, H. W. Henn and M. Niss (Eds.), Modelling and applications in mathematics education: 14th ICMI Study (pp. 325332). New York: Springer.

Çiltaş, A. (2011). Dizi ve Seriler Konusunun Matematiksel Modelleme Yoluyla Ögrretiminin İlköğretim Matematik Öğretmeni Adaylarının Öğrenme ve Modelleme Becerileri Üzerine Etkisi. Doktora Tezi. Erzurum: Atatürk Üniversitesi.

Doruk, B. K. (2010). Matematiği Günlük Yaşama Transfer Etmede Matematiksel Modellemenin Etkisi. Doktora Tezi. Ankara: Hacettepe Üniversitesi.

Erbaş, K. A., Çetinkaya, B., Alacacı, C., Çakırğolu, E., Aydoğan Yenmez, A., Şen Zeytun, A., vd. (2016). Lise matematik konuları için günlük hayattan modelleme soruları. Ankara: Türkiye Bilimler Akademisi.

Frejd, P. (2012). Teachers' Conceptions Of Mathematical Modelling At Swedish Upper Secondary School. Journal of Mathematical Modelling and Application, 1(5), 17-40.

Güder, Y. (2013). Ortaokul Matematik Öğretmenlerinin Matematiksel Modellemeye İlişkin Görüşleri. Yüksek Lisans Tezi. Elâzığ: Fırat Üniversitesi.

Işık, A., \& Mercan, E. (2015). Ortaokul Matematik Öğretmenlerinin Model ve Modelleme Hakkındaki Görüşlerinin İncelenmesi. Kastamonu Eğitim Dergisi, 23(4), 1835-1850.

Kaiser, G., \& Schwarz, B. (2006). Mathematical Modelling as Bridge Between School and University. Zentralblatt Für Didactik Der Mathematic, 38 (2), 196 - 208. 
Kertil, M. (2008). Matematik Öğretmen Adaylarının Problem Çözme Becerilerinin Modelleme Sürecinde Incelenmesi. Yüksek Lisans Tezi. İstanbul: Marmara Üniversitesi.

Lesh, R. A., \& Doerr, H. M. (2003). Foundations of models and modeling perspective on mathematics teaching, learning, and problem solving. In R. Lesh and H. M. Doerr (Eds.), Beyond constructivism: Models and modeling perspectives on mathematics problem solving, learning, and teaching (pp. 3-33). Mahwah, NJ: Lawrence Erlbaum Associates.

Lingefjärd, T. (2007). Mathematical modelling in teacher education- necessity or unnecessarily, In W. Blum, P. L. Galbraith, H. W. Henn and M. Niss (Eds.), Modelling and applications in mathematics education: 14th ICMI Study (pp. 333-340). New York: Springer.

Maaß, K. (2006). What Are Modeling Competencies? ZDM, 38(2),113-142.

Metin, M. (2014). Kuramdan uygulamaya ĕgitimde bilimsel araştırma yöntemleri. Ankara: Pegem Akademi Yayınları.

Miles, M. B., \& Huberman, M. A. (1994). Qualitative analysis: An expanded sourcebook. Thousand Oaks, CA: Sage.

Ortiz, J., \& Dos Santos, A. (2011). Mathematical modelling in secondary education: A case study. In G. Kaiser, W. Blum, R. B. Ferri and G. Stillman (Eds.), Trends in teaching and learning of mathematical modelling: ICTMA 14 (pp. 127-135). Netherlands: Springer.

Özer Keskin, Ö. (2008). Ortä̈ğretim Matematik Öğretmen Adaylarının Matematiksel Modelleme Yapabilme Becerilerinin Geliştirilmesi Üzerine Bir Araştırma. Doktora Tezi. Ankara: Gazi Üniversitesi.

Özturan Sağırlı, M. (2010). Türev Konusunda Matematiksel Modelleme Yönteminin Ortaögretim Öğrencilerinin Akademik Başarlart ve Öz-Düzenleme Becerilerine Etkisi. Doktora Tezi. Erzurum: Atatürk Üniversitesi.

Tekin Dede, A., \& Bukova Güzel, E. (2013). Matematik Öğretmenlerinin Model Oluşturma Etkinliği Tasarım Süreçleri ve Etkinliklere Yönelik Görüşleri. Bartın Üniversitesi Eğitim Fakültesi Dergisi, 2(1), 300-322.

Uğurel, I., \& Moralı S. (2006). Karikatürler ve Matematik Öğretiminde Kullanımı. Milli Ĕ̈itim Dergisi, 35(170), 32-47.

Urhan, S., \& Dost, Ş. (2016). Matematiksel Modelleme Etkinliklerinin Derslerde Kullanımı: Öğretmen Görüşleri. Elektronik Sosyal Bilimler Dergisi, 15(59), 12791295.

Yıldırım, A., \& Şimşek, H. (2008). Sosyal bilimlerde nitel araştırma yöntemleri (6. Baskı). Ankara: Seçkin Yayıncılık.

Yu, S. Y., \& Chang, C. K. (2011). What did taiwan mathematics teachers think of modeleliciting activities and modelling teaching?. In G. Kaiser, W. Blum, R. B. Ferri and 
G. Stillman (Eds.), Trends in teaching and learning of mathematical modelling: ICTMA 14 (pp. 147-156). Netherlands: Springer.

Zawojewski, J. S., Lesh, R., \& English, L. D. (2003). A models and modelling perspective on the role of small group learning. In R. A. Lesh and H. Doerr (Eds.), Beyond constructivism: Models and modeling perspectives on mathematics problem solving, learning, and teaching (pp. 337-358). Mahwah, NJ: Lawrence Erlbaum. 
